\title{
2 Antibiosis of vineyard ecosystem fungi against food-borne microorganisms
}

3

4 Carolina Cueva ${ }^{\mathrm{a}}$, M.Victoria Moreno-Arribas ${ }^{\mathrm{a}^{*}}$, Begoña Bartolomé $^{\mathrm{a}}$, Óscar Salazar ${ }^{\mathrm{b}}$, M.Francisca Vicente ${ }^{c}$, Gerald F. Bills ${ }^{c}$

6

7

8 a Instituto de Investigación Ciencias de la Alimentación (CIAL), CSIC-UAM, C/Nicolás

9 Cabrera 9, Campus de Cantoblanco, 28049 Madrid, Spain

$10 \quad{ }^{\mathrm{b}}$ Genómica S.A.U (Zeltia), Alcarria 7, 28823 Madrid, Spain

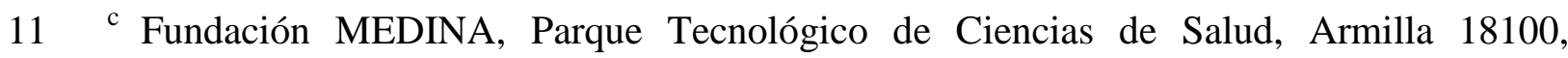

12 Granada, Spain

13

14

15 carolina.cueva@csic.es

16 victoria.moreno@csic.es “*Correspondence and reprints”

17 bartolome@ifi.csic.es

18 osalazar@genomica.es

19 francisca.vicente@medinaandalucia.es

20 gerald.bills@medinaandalucia.es

21

22 


\section{$1 \quad$ Abstract}

2 Fermentation extracts from fungi isolated from vineyard ecosystems were tested for

3 antimicrobial activities against a set of test microorganisms, including five food-borne

4 pathogens (Staphylococcus aureus EP167, Acinetobacter baumannii (clinical isolated),

$5 \quad$ Pseudomonas aeruginosa PAO1, Escherichia coli O157:H7 (CECT 5947) and Candida

6 albicans MY1055) and two probiotic bacteria (Lactobacillus plantarum LCH17 and

7 Lactobacillus brevis LCH23). A total of 182 fungi were grown in eight different media,

8 and the fermentation extracts were screened for antimicrobial activity. A total of 71 fungi

9 produced extracts active against at least one pathogenic microorganism, but not against

10 any probiotic bacteria. The Gram-positive bacterium, Staphylococcus aureus EP167, was

11 more susceptible to antimicrobial fungi broths extracts than Gram-negative bacteria and

12 pathogenic fungi. Identification of active fungi based on internal transcribed spacer rRNA

13 sequence analysis revealed that species in the orders Pleosporales, Hypocreales and

14 Xylariales dominated. Differences in antimicrobial selectivity were observed among

15 isolates from the same species. Some compounds present in the active extracts were

16 tentatively identified by liquid chromatography-mass spectrometry. Antimicrobial

17 metabolites produced by vineyard-ecosystem fungi may potentially limit colonization and

18 spoilage of food products by food-borne pathogens, with minimal effect on probiotic

19 bacteria.

\section{Keywords}

22 Antimicrobial screening; fungi; vineyard ecosystem; food-borne microorganisms; secondary metabolites 


\section{1. Introduction}

2 Foods are commonly contaminated by pathogenic bacteria and yeasts that may cause

3 food spoilage and food-borne diseases in humans (Ray, 1996; Vazquez et al., 1993;

4 Velusamy et al., 2010), especially in hospital environments. In contrast, occurrence of

5 probiotic bacteria in food, such as bifidobacteria and lactobacilli, confers health benefits to

6 the host (Lebeer et al., 2008). New trends recommend the reduction of the use of

7 chemically synthesized preservatives in favour of natural alternatives that guarantee

8 sufficiently prolonged shelf-life of foods and ensure food safety with respect to food-borne

9 pathogens. In the search for use molecules, microorganisms have emerged as an effective

10 source of natural substances that could be used as preservatives in order to ensure food

11 preservation and safety (Wiyakrutta et al., 2004).

12 Fungi are well-known to produce both beneficial and deleterious natural products for 13 human health and nutrition (Demain, 2000) and continue to be investigated as useful 14 sources of natural products -secondary metabolites- (Hoffmeister et al., 2007) for their 15 potential medical, industrial and agricultural use (Bills et al., 1994; Calvo et al., 2002; Li 16 et al., 2005; Liu et al., 2008). Natural products screening programmes have often focused 17 on searching of antibiotics (Basilio et al., 2003; González del Val et al., 2001; Peláez et 18 al., 1998; Suay et al., 2000), although some antibiotically-active molecules could have 19 unexpected alternative applications (Demain, 1998). Antibiotic screening does not only 20 provide candidate compounds useful for a target application, but also antibiotic activity 21 may be indicative of complementary bioactivities and suggests high priority status for 22 broad-based pharmacological, microbiological, molecular biological, and agricultural 23 testing of the fungi-originated compound or mixture compounds (Demain, 1998).

24 Grapevines (Vitis vinifera L.) are one of the most important fruit species worldwide 25 because their fruit is the basis of wine production (Ali et al., 2009). In their natural 
1 environment, grapevine trunks are a host to a number of fungi and yeasts. The fungi most

2 frequently isolated from grapevine ecosystem are Fusarium spp, Cylindrocarpon spp,

3 Alternaria spp, Penicillium spp, Trichoderma spp, and Pestalotiopsis spp (Halleen et al.,

4 2003). Regarding secondary metabolites produced by grapevine fungi; most of the

5 previous studies have focused on pathogenic fungi such as Botryosphaeria obtusa,

$6 \quad$ Botrytis cinerea and Eutypa lata (Djoukeng et al., 2009; González Collado et al., 2007;

7 Jiménez Teja et al., 2006; Molyneux et al., 2002). We have built a collection of fungi

8 associated from these environments to explore for potential applications of their metabolic

9 products, including their enzymes, small molecular weight metabolites, and genomic

10 DNAs.

11 Using components of this collection, we set out to test the hypothesis that vineyard 12 ecosystem fungi might produce natural products able to selectively inhibit food-borne

13 pathogens without limiting the growth of beneficial probiotic bacteria. The pathogenic

14 microorganisms evaluated were: E. coli O157:H7 (CECT 5947), Pseudomonas aeruginosa

15 PAO1, Staphylococcus aureus EP167, Acinetobacter baumannii (clinical isolated) and

16 Candida albicans MY1055, and the probiotic bacteria Lactobacillus plantarum LCH17

17 and Lactobacillus brevis LCH23. DNA from the fungi whose extracts showed selective

18 antimicrobial activity against pathogens was purified and their internal transcribed spacer

19 rRNA regions were amplified and sequenced for molecular identification. Additionally,

20 active extracts were also analysed by liquid chromatography-mass spectrometry (LC-MS)

21 for identification of active compounds. 


\section{2. Materials and methods}

2

3

4

5

6 Guadalajara (Tortuero, $(\mathrm{T})$ ) and one location in the province of Ciudad Real (Membrilla,

7 (M)), all in Central Spain. To isolate endophytic fungi, grapevine stems were cut from

8 grapevine plants, place in clean paper envelopes, and transported to the laboratory at

9 ambient temperature in the same day. Samples were stored at $4{ }^{\circ} \mathrm{C}$ up to $48 \mathrm{~h}$ before

10 processing. Bark and leaf bud surfaces were disinfected by sequential $30 \mathrm{sec}$ washes in

$1170 \%$ ethanol, $5 \%$ sodium hypochlorite, $70 \%$ ethanol and sterile water (bark samples), and

$1270 \%$ ethanol and sterile $\mathrm{H}_{2} \mathrm{O}$ (leaf bud samples). To obtain xylem samples, grapevine stems were split at the distal end to expose the fresh uncontaminated xylem, and small chips were removed aseptically from the centre of the stem's interior with a sterile scalpel and forceps. After surface decontamination, individual bark fragments, xylem chips and leaf buds were aseptically transferred to each well of 48-well tissue culture plates containing YMC medium [malt extract (Becton Dickinson), $10 \mathrm{~g}$; yeast extract (Becton Dickinson), $2 \mathrm{~g}$; agar (Conda), $20 \mathrm{~g}$; cyclosporin A, $4 \mathrm{mg}$; streptomycin sulfate, $50 \mathrm{mg}$; terramycin, $50 \mathrm{mg}$; distilled water $1 \mathrm{~L}$. Eighteen 48-well microplates were prepared per plant (six for bark fragments, six for xylem chips and six for leaf buds). Isolation plates were dried briefly in a laminar flow hood to remove excess liquid from agar surfaces, and incubated for two weeks at $22{ }^{\circ} \mathrm{C}$ and $70 \%$ relative humidity.

Soil samples were sieved before fungi isolation. Soils aliquots were first washed and separated into particles using a particle filtration method in order to reduce the number of colonies of heavily sporulating fungi (Bills et al., 2004). Washed soil particles were plated 
1 using a dilution-to-extinction strategy (Collado et al., 2007; Sánchez Márquez et al.,

2 2011). Approximately $0.5 \mathrm{~cm}^{2}$ of washed soil particles were resuspended in $30 \mathrm{~mL}$ of

3 sterile $\mathrm{H}_{2} \mathrm{O}$. Ten-microliter aliquots of particle suspensions were pipetted per well into 48-

4 well tissue culture plates containing YMC medium. Nine (three per dilution) 48-well

5 microplates were prepared per sample. Isolation plates were dried briefly in a laminar flow

6 hood to remove excess liquid from agar surfaces, and incubated for two weeks at $22{ }^{\circ} \mathrm{C}$

7 and $70 \%$ relative humidity.

8 From each type of isolation plate, individual colonies were transferred to YM plates

9 [malt extract, $10 \mathrm{~g}$; yeast extract, $2 \mathrm{~g}$; agar, $20 \mathrm{~g} ; 1 \mathrm{~L}$ distilled $\mathrm{H}_{2} \mathrm{O}$ ] and incubated for 3

10 weeks. Isolates were classified into 'morphospecies' on the basis of colony morphology

11 (Bills et al., 2004). Morphospecies groupings were re-evaluated and consolidated

12 following analyses of internal transcribed spacer (ITS) sequence data, and representative

13 isolates were selected for screening. Representative strains were preserved as frozen agar

14 plugs in vials containing $10 \%$ glycerol at $-80{ }^{\circ} \mathrm{C}$. Strains are available from Fundación

15 MEDINA Culture Collection, Granada, Spain (www.medinaandalucia.es).

17 2.2. Fungal fermentation and metabolite extraction

18 Media formulations, tools and protocols for fermenting fungi in nutritional arrays

19 and extracting metabolites from mycelium have been described previously (Bills et al.,

20 2008, 2009; Duetz et al., 2010; Vicente et al, 2009). Briefly, each strain was grown as a

21 liquid hyphal suspension in tubes. Hyphal suspensions from sets of 80 strains were

22 transferred to the centre 80 wells of a master plate. Inoculum in the master plate was

23 replicated with a pin tool across eight new plates each containing different fermentation

24 medium at $1 \mathrm{~mL}$ per well to generate an eight-medium by 80 strain nutritional arrays. 
To extract each well of the nutritional array, the mycelia adhering to the well walls were gently dislodged by introducing a block of fixed $200 \mu \mathrm{L}$ pipette tips five times, and $850 \mu \mathrm{L}$ of acetone was added to each well. Plates were sealed with a silicone mat and were shaken for $30 \mathrm{~min}$ in one direction, and $30 \mathrm{~min}$ in the opposite direction, at $220 \mathrm{rpm}$ and $22^{\circ} \mathrm{C}$. To retain metabolites in solution, $170 \mu \mathrm{L}$ of dimethyl sulfoxide (DMSO) was added to each well, and after 5 min shaking, the acetone was evaporated in a Genevac HT-24 vacuum centrifuge for 75 min. Plates were opened in a chemical fume hood and air dried for about $2 \mathrm{~h}$ more. Extracted mycelium was pushed to the bottom of the wells with a metal plunger (Duetz et al., 2010). About $500 \mu \mathrm{L}$ of the acetone-medium supernatant from each well was transferred to $800 \mu \mathrm{L}$-well assay plates (AB-gene AB-0765). After addition of $165 \mu \mathrm{L}$ of water, each well contained an aqueous $665 \mu \mathrm{L}$ sample that was $0.75 \times$ the concentration of the original fermentation and contained 20\% DMSO. Extracts were stored at $-4{ }^{\circ} \mathrm{C}$ for 2 days and were briefly shaken on a MicroMix plate mixer prior to assay.

\subsection{Evaluation of the antimicrobial activity}

Test microorganisms and assay plates. In vitro antimicrobial activity susceptibility was determined by using a panel of seven microorganisms (Table 1). The probiotic strains were kindly provided by Dr. J.M. Rodriguez from the Department of Nutrition and Food and Science Technology, Universidad Complutense de Madrid (Madrid, Spain) and included: L. plantarum LCH17 and L. brevis LCH23, which were isolated from milk of healthy mothers (Jiménez et al., 2008; Martín et al., 2003). The human pathogenic reference strains, E. coli O157:H7 (CECT 5947; virulence factor deleted) was obtained from the Spanish Type Culture Collection (CECT), whereas Acinetobacter baumannii (clinical isolated), Candida albicans MY1055, Staphylococcus aureus EP167 (methicillin- 
1 susceptible $S$. aureus) (Novick, 1990), and Pseudomonas aeruginosa PAO1 (Holloway et

2 al., 1979) were from the Fundación MEDINA Culture Collection. Culture maintenance,

3 assay growth conditions and antibiotics used as positive and negative control have been

4 detailed previously (Cueva et al., 2010) and are summarized in Table 1.

Antimicrobial activity assay. For screening the antimicrobial activity of fungal

6 fermentation extracts, antimicrobial activity assay were carried out as described previously

7 Cueva et al. (2010). Inhibition percentage values considered active were: $\geq 30 \%$ for $C$.

8 albicans MY1055, $\geq 50 \%$ for A. baumanii 5973, E. coli CECT 5947 and P.aeruginosa

9 PAO1, and $\geq 60 \%$ for S. aureus EP167. The minimal values were selected based on

10 effective fungi extracts resistance of the strains, which is strain-dependent. This approach,

11 commonly used to study of natural products (Bills et al., 2008; Vicente et al., 2009),

12 selects cut-off values high enough in order to obtain a repeatability of results.

2.4. Liquid chromatography-mass spectrometry (LC-MS) and database matching of known antimicrobial metabolites

Metabolites in fermentation extracts were matched to a proprietary reference library 17 of fully characterized fungal metabolites and authentic samples using an in-house 18 developed application where the diode array signal, retention time, positive and negative 19 mass spectra of the active samples were compared to those of library (Bills et al., 2009;

20 Vicente et al., 2009). Active extracts $(2 \mu \mathrm{L})$ were analysed with an Agilent (Santa Clara, 21 CA) 1100 single Quadrupole LC-MS, coupled to a Zorbax SB-C8 column (2.1 x $30 \mathrm{~mm})$, maintained at $40{ }^{\circ} \mathrm{C}$ at a flow rate of $300 \mu \mathrm{L} / \mathrm{min}$. Solvent A consisted of $10 \%$ acetonitrile, $90 \% \mathrm{H}_{2} \mathrm{O}, 1.3 \mathrm{mM}$ trifluoroacetic acid and $1.3 \mathrm{mM}$ ammonium formate, while solvent $\mathrm{B}$ 24 was $90 \%$ acetonitrile, $10 \%$ water, $1.3 \mathrm{mM}$ trifluoroacetic acid and $1.3 \mathrm{mM}$ ammonium 25 formate. The gradient started at $10 \% \mathrm{~B}$ and went to $100 \% \mathrm{~B}$ in 6 minutes, kept at $100 \% \mathrm{~B}$ 
1 for 2 min and returned to $10 \%$ for 2 min to initialize the system. Full diode array UV scans

2 from 100 to $900 \mathrm{~nm}$ were collected in $4 \mathrm{~nm}$ steps at $0.25 \mathrm{sec} / \mathrm{scan}$. The eluting solvent was

3 ionized using the standard Agilent 1100 ESI source adjusted to a drying gas flow of 11

$4 \mathrm{~L} / \mathrm{min}$ at $325^{\circ} \mathrm{C}$ and a nebulizer pressure of $40 \mathrm{psig}$. The capillary voltage was set to 3500

5 V. Mass spectra were collected as full scans from $150 \mathrm{~m} / \mathrm{z}$ to $1500 \mathrm{~m} / \mathrm{z}$, with one scan

6 every $0.77 \mathrm{sec}$, in positive and negative modes. The possible origin of metabolites from

7 medium components was exclude by analysing negative controls, i.e. extracts of the sterile

8 media treated identically to cultures, in parallel.

\subsection{Molecular identification}

DNA extraction. Approximately $1 \mathrm{~mL}$ of fungi inoculum from each tube was transferred into 96-well plates with a Transfer Tube (Spectrum Laboratories, Rancho

13 Dominguez, CA, USA). Total genomic DNA from the different microorganisms was 14 isolated using a Master Pure ${ }^{\mathrm{TM}}$ Gram Positive DNA Purification Kit (Epicentre 15 Biotechnologies) following manufacturer's instruction; slight modifications were made in 16 order to improve fungi DNA extraction. The modifications carried out were as following: 17 a) some centrifugation steps were made twice (the first step of Gram Positive DNA 18 Purification Protocol and the seventh step in the DNA Precipitation), b) the volume of 19 isopropanol added for DNA precipitation was $300 \mu \mathrm{L}$, followed of drying step in a 20 Genevac HT-24 vacuum centrifuge at $45^{\circ} \mathrm{C}$ for $15 \mathrm{~min}$, and c) DNA extracts were 21 resuspended in $100 \mu \mathrm{L}$ of Milli-Q water. PCR amplification. DNA extracted was used for PCR amplification. DNAs were subjected to PCR reactions with primers ITS1 and ITS4 (White et al., 1990). Reactions 24 were performed in a final volume of $50 \mu \mathrm{L}$ containing $0.2 \mathrm{mM}$ of the four dNTPs (Applied Biosystems), $0.05 \mu \mathrm{M}$ of each primer, $5 \mu \mathrm{L}$ of the extracted DNA (about $10 \mathrm{ng} / \mu \mathrm{l}$ ) and 0.5 
1 U Taq polymerase (Appligene, Illkirch, France) with its appropriate reaction buffer.

2 Controls without fungi DNA were included for each PCR experiment. Amplifications 3 were performed in a Thermocycler PCR PTC-200 (Bio-Rad), according to the following 4 profile: 40 cycles of $1 \mathrm{~min}$ at $95^{\circ} \mathrm{C}, 1 \mathrm{~min}$ at $51^{\circ} \mathrm{C}$ and $2 \mathrm{~min}$ at $72^{\circ} \mathrm{C}$. Amplifications 5 products were visualized by electrophoresis in $1 \%$ agarose gels (Invitrogen E-Gel ${ }^{\circledR} 481 \%$ 6 (GP) G8008-01) using an Invitrogen E-Base. PCR products were purified using Ilustra 7 GFX 96 PCR Purification Kit (Amersham Biosciences).

8 DNA sequencing and sequence analysis. PCR primers ITS1 and ITS 4 were used for

9 the amplification of the ITS1-5.8S-ITS2 region of the wild-type isolates. The PCR 10 products were purified and used as a template in sequencing reactions with the primers 11 ITS1 and ITS4. Amplified and cloned DNA fragments were sequenced by using an ABI 12 Prism Dye terminator cycle sequencing kit (Amersham Biosciences). Sequences were 13 aligned using CLUSTAL W (Thomson et al., 1994). The analysis was complemented with 14 ITS1-5.8S-ITS2 sequences of fungal species available in GenBank and with similarity 15 searches using BLAST. 


\section{3. Results and discussion}

2

3

4

\subsection{Isolation of fungi}

Following surface disinfection methods, a total of 290 strains were isolated from samples of vineyard soil and plants from four locations of Spain: 30 from Villamanrique del Tajo (VT), 97 from Escuela de la Vid (EV), 101 from Membrilla (M), and 62 from Tortuero (T). An initial visual screening was carried out to discard identical isolates. As a result, a total of 182 fungal isolates were selected for the antimicrobial activity assays. The large number of fungal species confirmed that vineyard environment was an important source of potentially-active fungi.

\subsection{Antimicrobial activity of fungi extracts}

Each fungal isolate was grown in eight different media to promote the development of each strain's full capacity to produce secondary metabolites. Therefore, a total of 1456 extracts were assayed for antimicrobial activity against five food-borne pathogenic strains (S. aureus EP167, A. baumannii (clinical isolated), P. aeruginosa PAO1, E. coli O157:H7 (CECT 5947) and C. albicans MY1055) and two probiotic strains (L. plantarum LCH17 and L. brevis LCH23). A total of 71 fungi isolates met or exceeded the minimal antimicrobial activity in at least one of the eight growth conditions and resulted inactive against the two probiotic bacteria. Among these active fungi, 13 of them showed antimicrobial activity against two pathogenic strains or more (Table 2). However, the majority of them inhibited selectively the growth of only one pathogenic strain (Table 3). Regarding antibacterial resistance, Gram-positive $S$. aureus EP167 was the most susceptible to fungal extracts, whereas A. baumannii, E. coli O157:H7 and P. aeruginosa PAO1 (Gram negative) were more resistant. These results are consistent with the fact that 
1 Gram negative bacteria are characterised by an outer membrane that provides the cell with

2 a hydrophilic surface that is able to exclude certain hydrophobic molecules, therefore

3 imparting intrinsic resistance of these bacteria to antimicrobial compounds (Perry et al., 4 2009).

Bacterial and fungal food infections pose a health threat, most notably in

6 immunocompromised subjects. S. aureus is an opportunistic human pathogen, causing

7 major problems in the food sector as well as the clinic (Rode et al., 2007). Regarding

8 Gram negative strains, E. coli $\mathrm{O} 157: \mathrm{H} 7$ is a pathogen that causes haemorrhagic colitis,

9 haemolytic uremic syndrome and thrombotic thrombocytopaenic purpura (Charimba et al.,

10 2010); P. aeruginosa is a nosocomial pathogen that causes urinary tract infections, 11 respiratory system infections, dermatitis, and gastrointestinal infections; A. baumannii is 12 implicated in a variety of nosocomial infections, including bacteremia, urinary tract 13 infection and pneumonia (Bergogne-Bérézin et al., 1996). On the other hand, dietary 14 contamination with the yeast $C$. albicans may cause opportunistic mouth infections 15 (Rauha et al., 2000). In contrast, the occurrence of probiotic bacteria in food, such as 16 Lactobacillus plantarum LCH17 and Lactobacillus brevis LCH23 confer a health benefit 17 to the host. One of the mechanisms exerting health promoting effects in human beings is 18 pathogen inhibition and restoration of microbial homeostasis through microbe-microbe 19 interactions. This capacity has been a major principal for food preservation (Lebeer et al., 20 2008). Although the techniques to preserve food safety are improving, pathogenic 21 microorganisms such as used in this study may be ingested in the human body through 22 contaminated food, which could provoke serious problems on human health, especially in 23 hospitalized patients whose immune system are debilitated. 
The sequences from each strain were compared with sequences in the GenBank

2 database to approximate fungi identification. Best GenBank Blast match identifications

3 and GenBank accession numbers of fungi causing antimicrobial activity are provided in

$4 \quad$ Tables 2 and 3. These fungi belonged mostly to the Dothideomycetes and Sordariomycetes

5 classes. The most frequently active fungi were Alternaria spp, Coelomycete strains,

6 Aspergillus spp, Fusarium spp, Discostroma spp, Penicillium spp, Leptosphaeria spp and

7 Pestalotiopsis spp. The distribution of fungal tax is consistent with the report of Halleen et

8 al. (2003). These fungi apparently were not restricted to any particular location. The

9 common phytophatogens, Botryosphaeria sp and Phaeoacremonium sp were also found.

10 These pathogens are associated with black dead arm and esca disease respectively

11 (Djoukeng et al., 2009; Larignon et al., 1997; Sánchez-Torres et al., 2008). Sequences of

12 some fungi could not be identified (unidentified fungus) because of lack of comparative

13 sequences in the Genbank database (results not shown). Antifungal activities were most

14 frequently detected in strains from the order Pleosporales, and the most potent

15 antibacterial activity was found in the strains of the order Hypocreales. Some of the results

16 reported in this study are consistent with those from earlier studies in other fungi sources.

17 For example, it is known that members of group Eurotiales, Hypocreales and

18 Pleosporales consistently produce antibacterial and antifungal metabolites (Peláez et al.,

19 1998; Suay et al., 2000).

20 The two fungi whose extracts showed activity against all the pathogens were 21 Aspergillus niger (E-000535890) and Epicoccum nigrum (E-000535780) (Table 2). Other 22 strains of E. nigrum (E-000535735) were active but only against A. baumannii (Table 3 )

23 As seen for other isolates, antimicrobial selectivity of fungi extracts varied slightly among

24 strains of the same species (Table 2 and 3). Similar intraspecific variability was also 
1 described by Möller et al. (1997) for Chaunopycnis alba and by Peláez et al. (1998) for

2 Pseudodiploidia sp and Sporomiella intermedia.

3

\section{3.4. Identification of bioactive metabolites}

An attempt to confirm the antimicrobial potential of extracts from vineyard

6 ecosystem fungi, known antimicrobial metabolites in the active extracts were identified by

7 LC-MS database matching, taking into account that these metabolites might not be the

8 agent responsible for the antimicrobial activity of the extracts. Liquid chromatography-

9 mass spectrometry identified thirteen known metabolites considered of broad

10 antimicrobial spectra (Tables 2 and 3). In addition, other yet uncharacterized metabolites

11 were recognized (results not shown), which are a candidates for purifying of antibacterial

12 and antifungal metabolites.

13 Most of the extracts containing the compounds identified in Tables 2 and 3 showed

14 antimicrobial activity against S. aureus EP167. As described previously Peláez et al.

15 (1998), when the antimicrobial activity exerted by extracts are specific to one pathogen it

16 is more probably that a single compound was responsible for this activity, however, when

17 the inhibition acts across different type of pathogen microorganisms, it is unclear whether

18 the activity detected is caused by a single inhibitor of against both types of

19 microorganisms, or rather a mixture of compounds with different specificities.

20 Previous studies have been reported that some of the compounds identified in our

21 study have biological activities. Thus, asterric acid have reported that performed such as

22 endothelin binding inhibitor (Ohashi et al., 1992) and inhibitor of vascular endothelial

23 growth factor (VEGF) (Lee et al., 2002); enniantins, roridins and ergosterol have showed

24 anticarcinogenic properties (Amagata et al., 2003; Dornetshuber et al., 2007; Wätjen et al.,

25 2009; Yazawa et al., 2000) and equisetin have showed inhibition of recombinant integrase 
1 enzyme (Singh et al., 1998) and inhibition of the substrate anion carriers of the

2 mitochondrial inner membrane in rats (Konig et al., 1993). However, most of these

3 compounds are likely to be toxic and their use to control food pathogens would be

4 inappropriate. Recently Strobel (2003) and Liu et al. (2008) described the ability of

5 Xylaria sp YX-28 fungi to produce an antimicrobial compound (7-amino-4-

6 methlcoumarin) with the potential to be used as a food additive. Therefore, further

7 investigation should focus on the causes of antibiosis from extracts from unknown fungal

8 strains.

9 In summary, our results confirm that grapevine environments are abundantly 10 populated with fungi producing bioactive secondary metabolites that could have an 11 interesting application in the food industry. A significant number of fungi strains whose 12 extracts have proven antimicrobial effects against food-borne pathogens but not against 13 any probiotic bacteria, were isolated and identified by molecular approaches. This opens 14 the possibility of fungi metabolites to be used as antimicrobials preventing food 15 deterioration and infections in human beings. However, further investigations are needed 16 in order to identify the active compounds produced by the grapevine environment fungi.

18 Acknowledgements

19 Research project was funded by the Spanish Ministry for Science and Innovation 20 (AGL2009-13361-C02-01, AGL2006-04514 and CSD2007-00063 Consolider Ingenio 212010 FUN-C-FOOD Projects), and the Comunidad de Madrid (S-0505/AGR/0153 Project).

$22 \mathrm{CC}$ is the recipient of fellowships from the FPI-MEC program. The authors are grateful to J.

23 Martin for technical assistance in the liquid chromatography-mass spectrometry. 


\section{References}

2 Amagata, T., Rath, C., Rigot, J.F., Tarlov, N., Tenney, K., Valeriote, F.A., Crews, P.,

3 2003. Structures and cytotoxic properties of trichoverroids and their macrolide analogues

4 produced by saltwater culture of Myrothecium verrucaria. J. Med. Chem. 46, 4342-4350.

6 Ali, K., Maltese, F., Zyprian, E., Rex, M., Choi,Y.H., Verpoorte, R., 2009. NMR

7 Metabolic Fingerprinting Based Identification of Grapevine Metabolites Associated with

8 Downy Mildew Resistance. J. Agric. Food Chem. 57, 9599-9606.

9

10 Basilio, A., González, I., Vicente, M.F., Gorrochategui, J., Cabello, A., González, A., 11 Genilloud, O., 2003. Patterns of antimicrobial activities from soil actinomycetes isolated 12 under different conditions of $\mathrm{pH}$ and salinity. J. Appl. Microbiol. 95, 814-823.

14 Bergogne-Bérézin, E., Towner, K.J., 1996. Acinetobacter spp. as Nosocomial Pathogens: 15 Microbiological, Clinical, and Epidemiological Features. Clin. Microbiol. Rev. 9, 14816165.

Bills, G.F., Pelaez, F., Polishook, J.D., Diez-Matas, M.T., Harris, G.H., Clapp, W.H.,

19 Dufresne, C., Byrne, K.M., Nallin-Omstead, M., Jenkins, R.G., Mojena, M., Huang, 20 Leeyuan., Bergstrom, J.D., 1994. Distribution of zaragozic acids (squalestatins) among 21 filamentous ascomycetes. Mycological Res. 98, 733-739.

23 Bills, G.F., Platas, G., Gams, W., 2004. Conspecificity of the cerulenin and helvolic acid 24 producing 'Cephalosporium caerulens', and the hypocrealean fungus Sarocladium oryzae. 25 Mycological Res. 108, 1291-1300. 
1 Bills, G.F., Platas, G., Fillola, A., Jiménez, M.R., Collado, J., Vicente, M.F., Martín, J.,

2 González, A., Bur-Zimmermann, J., Tormo, J.R., Peláez, F., 2008. Enhancement of 3 antibiotic and secondary metabolite detection from filamentous fungi by growth on 4 nutritional arrays. J. Appl. Microbiol. 104, 1644-1658.

6 Bills, G.F., Martín, J., Collado, J., Platas, G., Overy, D., Tormo, J.R., Vicente, M.F., 7 Verkley, G., Crous, P.W., 2009. Measuring the distribution and diversity of antibiosis and 8 secondary metabolites in the filamentous fungi. Soc. Ind. Microbiol. News 59, 133-146.

10 Calvo, A.M., Wilson, R.A., Bok, J.W., Keller, N.P., 2002. Relationship between 11 secondary metabolism and fungal development. Microbiol. Molec. Biol. Rev. 66, 447-459.

13 Chaffin, W.L., 2008. Candida albicans cell wall proteins. Microbiol. Mol. Biol Rev. 72, $14 \quad 495-544$.

16 Charimba, G., Hugo, C.J., Hugo, A., 2010. The growth, survival and thermal inactivation 17 of Escherichia coli $\mathrm{O} 157: \mathrm{H} 7$ in a traditional South African sausage. Meat Sci. 85, 89-95.

18 Cueva, C., Moreno-Arribas, M.V., Martín-Álvarez, P.J., Bills, G.F., Vicente, M.F.,

19 Basilio, A., López Rivas, C., Requena, T., Rodríguez, J.M., Bartolomé, B., 2010.

20 Antimicrobial activity of phenolic acids against commensal, probiotic and pathogenic 21 bacteria. Res. Microbiol. 161, 372-382.

23 Collado, J., G. Platas, B. Paulus \& G.F. Bills., 2007. High-throughput culturing of fungi 24 from plant litter by a dilution-to-extinction technique. FEMS Microbiol. Ecol. 60, 52125533. 
2 Demain, A.L., 1998. Microbial natural products: Alive and well in 1998. Nat. Biotechnol. $3 \quad 16,3-4$.

4

5 Demain, A.L., Fang, A., 2000. The natural functions of secondary metabolites. Adv. 6 Biochem. Eng./Biotechnol. 69, 1-39.

7

8 Djoukeng, J.D., Polli, S., Larignon, P., Abou-Mansour, E., 2009. Identification of 9 phytotoxins from Botryosphaeria obtusa, a pathogen of black dead arm disease of 10 grapevine. Eur. J. Plant. Pathol. 124, 303-308.

12 Dornetshuber, R., Heffeter, P., Kamyar, M.R., Peterbauer, T., Berger, W., Lemmens-

13 Gruber, R., 2007. Enniatin exerts p53-dependent cytostatic and p53-independent cytotoxic 14 activities against human cancer cells. Chem. Res. Toxicol. 20, 465-473.

16 Duetz, W., Chase, M., Bills, G., 2010. Miniaturization of fermentations, in: Demain, A., 17 Davies, J., Baltz, R. (Eds.), Manual of Industrial Microbiology and Biotechnology, 3rd. 18 ASM Press., Washington, pp. 99-116.

20 González Collado, I., Macías Sánchez, A.J., Hanson, J.R., 2007. Fungal terpene 21 metabolites: biosynthetic relationships and the control of the phytopathogenic fungus 22 Botrytis cinerea. Nat. Prod. Rep. 24, 674-686.

24 González del Val, A., Platas, G., Basilio, A., Cabello, A., Gorrochategui, J., Suay, I., 25 Vicente, M.F., Portillo, E., Jiménez del Río, M., García Reina, G., Peláez, F., 2001. 
1 Screening of antimicrobial activities in red, green and brown macroalgae from Canaria

2 (Canary Islands, Spain). Int. Microbiol. 4, 35-40.

3

4 Jiménez, E., Fernández, L., Maldonado, A., Martín, R., Olivares, M., Xaus, J., Rodríguez, 5 J.M., 2008. Oral administration of lactobacilli strains isolated from breast milk as an 6 alternative for the treatment of infectious mastitis during lactation. Appl. Envir. Microb. $7 \quad 74,4650-4655$.

8

9 Jiménez-Teja, D., Hernández-Galán, R., González Collado, I., 2006. Metabolites from 10 Eutypa species that are pathogens on grapes. Nat. Prod. Rep. 23, 108-116.

12 Konig, T., Kapus, A., Sarkadi, B., 1993. Effects of equisetin on rat liver mitochondria:

13 Evidence for inhibition of substrate anion carriers of the inner membrane. J. Bioenerg. and 14 Biomems. 25, 537-545.

16 Halleen, F., Crous, P.W., Petrini, O., 2003. Fungi associated with healthy grapevine 17 cuttings in nurseries, with special reference to pathogens involved in the decline of young vines. Aust. Plant. Pathol. 32, 47-52.

Holloway, B.W., Krishnapillai, V., Morgan, A.F., 1979. Chromosomal genetics of 21 Pseudomonas. Microbiol. Rev. 43, 73-102.

23 Hoffmeister, D., Keller, N.P., 2007. Natural products of filamentous fungi: enzymes, 24 genes, and their regulation. Nat. Prod. Rep. 24, 393-413. 
1 Larignon, P., Dubos, B., 1997. Fungi associated with esca disease in grapevine. Eur. J.

2 Plant. Pathol. 103, 47-157.

3

4 Lebeer, S., Vanderleyden, J., De Keersmaecker, S.C.J., 2008. Genes and Molecules of 5 Lactobacilli Supporting Probiotic Action. Microbiol. Mol. Biol. Rev. 72, 728-764.

6

7 Lee, H.J., Lee, J.H., Hwang, B.Y., Kim, H.S., Lee, J.J., 2002. Fungal metabolites, asterric

8 acid derivatives inhibit vascular endothelial growth factor (VEGF)-induced tube formation

9 of HUVECs. J. Antibiot. 55, 552-556.

10

11 Li, Y., Song, YC., Liu, J.Y., Ma, Y.M., Tan, R.X., 2005. Anti-Helicobacter pylori 12 substances from endophytic fungal cultures. World J. Microbiol. Biotechnol. 21, 553-558.

14 Liu, X., Dong, M., Chen, X., Jiang, M., Lv, X., Zhou, J., 2008. Antimicrobial activity of 15 an endophytic Xylaria sp. YX-28 and identification of its antimicrobial compound 716 amino-4-methylcoumarin. Appl. Microbiol. Biotecnol. 78, 241-247.

18 Martín, R., Langa, S., Reviriego, C., Jiménez, E., Marín, M.L., Xaus, J., Fernández, L., 19 Rodríguez, J.M., 2003. Human milk is a source of lactic acid bacteria for the infant gut. J. 20 Pediatr. 143, 754-758.

22 Möller, C., Weber, G., Dreyfuss, M.M., 1997. Intraspecific diversity in the fungal species 23 Chaunopycnis alba: implications for microbial screening programs. J. Ind. Microbiol. 24 Biotechnol. 17, 359-372. 
1 Molyneux, R.J., Mahoney, N., Bayman, P., Wong, R.Y., Meyer, K., Irelan, N., 2002.

2 Eutypa lata Dieback in Grapevines: Differential Production of Acetylenic Phenol

3 Metabolites by Strains of Eutypa lata. J. Agric. Food. Chem. 50, 1393-1399.

4

5 Novick, R.P., 1990. The staphylococcus as a molecular genetic system, in: Novick, R.P. 6 (Eds.), Molecular biology of the staphylococci.VCH Publishers., New York, pp. 1-40.

7

8 Ohashi, H., Akiyama, H., Nishikori, K., Mochizuki, J.I., 1992. Asterric acid, a new

9 endothelin binding inhibitor. J. Antibiot. 45, 1684-1685.

10

11 Payne, K.D., Davidson, P.M., Oliver, S.P., Christen, G.L., 1990. Influence if bovine 12 lactoferrin on the growth of Listeria monocytogenes. J. Food Prot. 53, 468-72.

14 Peláez, F., Collado, J., Arenal, F., Basilio, A., Cabello, A., Díez Matas, M.T., García, J.B., 15 González del Val, A., González, V., Gorrochategui, J., Hernández, P., Martín, I., Platas, 16 G., Vicente, F., 1998. Endophytic fungi from plants living on gypsum soils as a source of 17 secondary metabolites with antimicrobial activity. Mycol. Res. 102, 755-761.

Sánchez-Torres, P., Hinarejos, R., González, V., Tuset, J.J., 2008. Identification and characterization of fungi associated with esca vineyards of the Comunidad Valenciana

21 (Spain). Spanish J. Agric. Res. 6, 650-660.

23 Singh, S.B., Zink, D.L., Goetz, M.A., Dombrowski, A.W., Polishook, J.D., Hazuda, D.J., 24 1998. Equisetin and a novel opposite stereochemical homolog phomasetin, two fungal 25 metabolites as inhibitors of HIV-1 integrase. Tetrah. Lett. 39, 2243-2246. 
2 Perry, C.C., Weatherly, M., Beale, T., Randriamahefa, A., 2009. Atomic force microscopy 3 study of the antimicrobial activity of aqueous garlic versus ampicillin against Escherichia

$4 \quad$ coli and Staphylococcus aureus. J. Sci. Food Agric. 89, 958-964.

5

6 Rauha, J.P., Remes, S., Heinonen, M., Hopia, A., Kahkonen, M., Kujala, T., Pihlaja, K.,

7 Vuorela, H., Vuorela, P., 2000. Antimicrobial effects of Finnish plant extracts containing

8 flavonoids and other phenolic compounds. Int. J. Food Microbiol. 56, 3-12.

9

10 Ray, B., 1996. Spoilage of Specific food groups, in: Fundamental Food Microbiology.

11 CRC Press., Boca Raton Florida, p. 220.

12

13 Rode, T.M., Langsrud, S., Holck, A., Moretro, T., 2007. Different patterns of biofilm

14 formation in Staphylococcus aureus under food-related stress conditions. Int. J. Food 15 Microbiol. 116, 372-383.

16

17 Sánchez Márquez, S., Bills, G.F., Zabalgogeazcoa I., 2011. Fungal species diversity in 18 juvenile and adult leaves of Eucalyptus globulus from plantations affected by 19 Mycosphaerella leaf disease. Ann. Appl. Biol. 158, 177-187.

20

21 Strobel, G., 2003. Endophytes as sources of bioactive products. Microbes. Infect. 5, 535544. 
1 Suay, I., Arenal, F., Asensio, F.J., Basilio, A., Cabello, M.A., Díez, M.T., García, J.B.,

2 González del Val, A., Gorrochategui, J., Hernández, P., Peláez, F., Vicente, M.F., 2000.

3 Screening of basidiomycetes for antimicrobial activities. Ant. van Leeuw. 78, 129-139.

4

5 Thompson, J.D., Higgins, D.G., Gibson, T.J., 1994. CLUSTAL W: improving the

6 sensitivity of progressive multiple sequence alignment through sequence weighting

7 position-specific gap penalties and weight matrix choice. Nucleic Acids Res. 22, 467384768.

9

10 Vazquez, J.A., Sánchez, V., Dmuchowski, C., Dembry, L.M., Sobel, J.D., Zervos, M.J., 11 1993. Nosocomial Acquisition of Candida albicans: An Epidemiologic Study. J. Infect. 12 Dis. 168, 195-201.

14 Velusamy, V., Arshak, K., Korostynska, O., Oliwa, K., Adley, C., 2010. An overview of 15 foodborne pathogen detection: In the perspective of biosensors. Biotechnol. Adv. 28, 23216354.

18 Vicente, F., Basilio, A., Platas, G., Collado, J., Bills, G.F., González del Val, A., Martín, 19 J., Tormo, J.R., Harris, G.H., Zink, D.L., Justice, M., Nielsen-Kahn, J., Peláez, F., 2009.

20 Distribution of the antifungal agents sordarins across filamentous fungi. Mycol. Res. 113, $21 \quad 754-770$.

23 Wätjen, W., Debbab, A., Hohlfeld, A., Chovolou, Y., Kampkötter, A., Edrada, R.A., Ebel, 24 R., Hakiki, A., Mosaddak, M., Totzke, F., Kubbutat, M.H.G., Proksch, P., 2009. Enniatins $25 \mathrm{~A} 1, \mathrm{~B}$ and B1 from an endophytic strain of Fusarium tricinctum induce apoptotic cell 
1 death in H4IIE hepatoma cells accompanied by inhibition of ERK phosphorylation. Mol.

2 Nutr. Food Res. 53, 431-440.

3

4 White, T.J., Bruns, T., Lee, S., Taylor, J.W., 1990. Amplification and direct sequencing of 5 fungal ribosomal RNA genes for phylogenetics, in: Innis, M.A., Gelfand, D.H., Sninsky, 6 J.J., White, T.J. (Eds.), PCR Protocols: A Guide to Methods and Applications. Academic $7 \quad$ Press., New York, pp. 315-322.

8

9 Wiyakrutta, S., Sriubolmas, N., Panphut, W., Thongon, N., Danwisetkanjana, K., 10 Ruangrungsi, N., Meevootisom, V., 2004. Endophytic fungi with anti-microbial, anto11 cancer and anti-malarial activities isolated from Thai medicinal plants. World J. 12 Microbiol. Biotechnol. 20, 265-272.

13

14 Yazawa, Y., Yokota, M., Sugiyama, K., 2000. Antitumor promoting effect of an active 15 component of polyporus, ergosterol and related compounds on rat urinary bladder 16 carcinogenesis in a short-term test with concanavalin A. Biol. Pharmaceut. Bull. 23, 1298171302. 
Table 1. Strains and growth conditions of the microorganisms.

\begin{tabular}{|c|c|c|c|c|}
\hline Strain & Growth medium & Incubation conditions & Positive control & Negative control \\
\hline A. baumannii (clinical isolated) & $\mathrm{MH}$ & $20 \mathrm{~h}, 37^{\circ} \mathrm{C}$ & Ciprofloxacin & Amphotericin B \\
\hline C. albicans MY1055 & RPMI modified & $20 \mathrm{~h}, 30^{\circ} \mathrm{C}$ & Amphotericin B & Penicillin G \\
\hline E. coli CECT 5947 & LB + chloramphenicol $(25 \mu \mathrm{g} / \mathrm{mL})$ & $18 \mathrm{~h}, 37^{\circ} \mathrm{C}$ & Ciprofloxacin & Novobiocin \\
\hline L. brevis LCH23 & MRS & $30 \mathrm{~h}, 37^{\circ} \mathrm{C}$ & Penicillin G & Amphotericin B \\
\hline L. plantarum LCH17 & MRS & $24 \mathrm{~h}, 37^{\circ} \mathrm{C}$ & Penicillin G & Amphotericin B \\
\hline P. aeruginosa $\mathrm{PAO} 1$ & LB & $20 \mathrm{~h}, 37^{\circ} \mathrm{C}$ & Ciprofloxacin & Amphotericin B \\
\hline S. aureus EP167 & LB + chloramphenicol $(34 \mu \mathrm{g} / \mathrm{mL})$ & $20 \mathrm{~h}, 37^{\circ} \mathrm{C}$ & Penicillin G & Amphotericin B \\
\hline
\end{tabular}


Table 2. Fungal strains whose extracts showed antimicrobial activity against two or more of the pathogens tested but were inactive against the probiotic bacteria. The taxa are cited in alphabetic order.

\begin{tabular}{|c|c|c|c|c|c|c|c|c|c|c|c|c|}
\hline Class & Order & Identified species & $\begin{array}{c}\text { GenBank } \\
\text { accession no. }\end{array}$ & Strain codes & Identified metabolites & $\begin{array}{c}\text { Substrate } \\
\text { type }\end{array}$ & Origin & Sta & Aci & Pse & Eco & Can \\
\hline \multirow[t]{2}{*}{ Dothideomycetes } & Pleosporales & Camarosporium spp & JN545797 & E-000535734 & Penicillic Acid & Xylem & $\mathrm{EV}$ & & + & & & + \\
\hline & & Epicoccum nigrum & JN545803 & E-000535780 & & Leaf bud & M & + & + & + & + & + \\
\hline \multirow[t]{5}{*}{ Eurotiomycetes } & Chaetothyriales & Exophiala spp & n.s. & E-000535881 & Ergosterol D & Soil & M & + & + & & & \\
\hline & Eurotiales & Aspergillus niger & JN545800 & E-000535890 & & Soil & $\mathrm{T}$ & + & + & + & + & + \\
\hline & & Aspergillus ustus & JN545824 & E-000535884 & & Soil & $\mathrm{T}$ & + & & & & + \\
\hline & & Aspergillus versicolor & JN545821 & E-000535879 & & Soil & M & + & & & & + \\
\hline & & Penicillium expasum & JN545825 & E-000535885 & Helvolic acid & Soil & $\mathrm{T}$ & + & + & & + & \\
\hline \multirow[t]{5}{*}{ Sordariomycetes } & Hypocreales & Fusarium spp & JN545775 & E-000535632 & Enniatin $(A, A 1, B 1, D)$, Fusarielin & Bark & VT & + & & & + & + \\
\hline & & Fusarium spp & JN545779 & E-000535644 & Beauvericin & Bark & VT & + & & & + & \\
\hline & & Myrothecium spp & JN545776 & E-000535633 & Roridin $(A, H)$, Verrucarin & Bark & VT & + & & & & + \\
\hline & & Paecilomyces marquandii & JN545822 & E-000535880 & & Soil & M & + & + & & & \\
\hline & $\begin{array}{l}\text { Unidentified } \\
\text { Hypocreales }\end{array}$ & & JN545830 & E-000535914 & Ergosterol D & Soil & $\mathrm{T}$ & & + & + & & \\
\hline Unidentified fungus & & & JN545794 & E-000535724 & & Bark & EV & + & + & & & \\
\hline
\end{tabular}

n.s.: not sequence

VT: Villamanrique del Tajo (Madrid, Spain), EV: Escuela de la Vid (Madrid, Spain), M: Membrilla (Ciudad Real, Spain), Tortuero (Guadalajara, Spain).

Sta: Staphylococcus aureus EP167, Aci: Acinetobacter baumannii (clinical isolated), Pse: Pseudomonas aeruginosa PAO1, Eco: Escherichia coli O157:H7 (CECT 5947), Can: Candida albicans MY1055. 
Table 3. Isolated fungi strains whose extracts showed antimicrobial activity against one of the pathogens tested but not against probiotic bacteria.

The taxa are cited in alphabetic order.

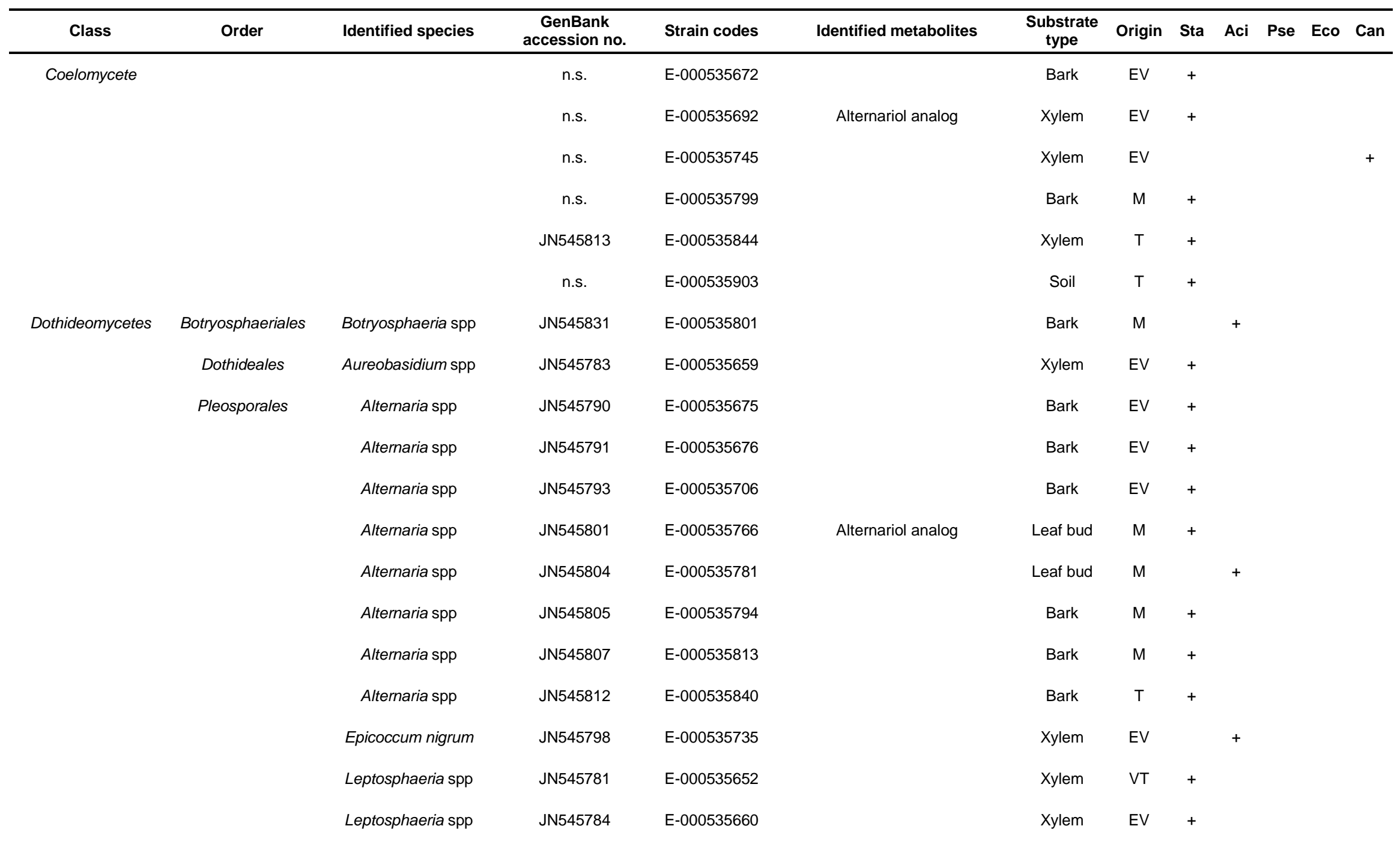




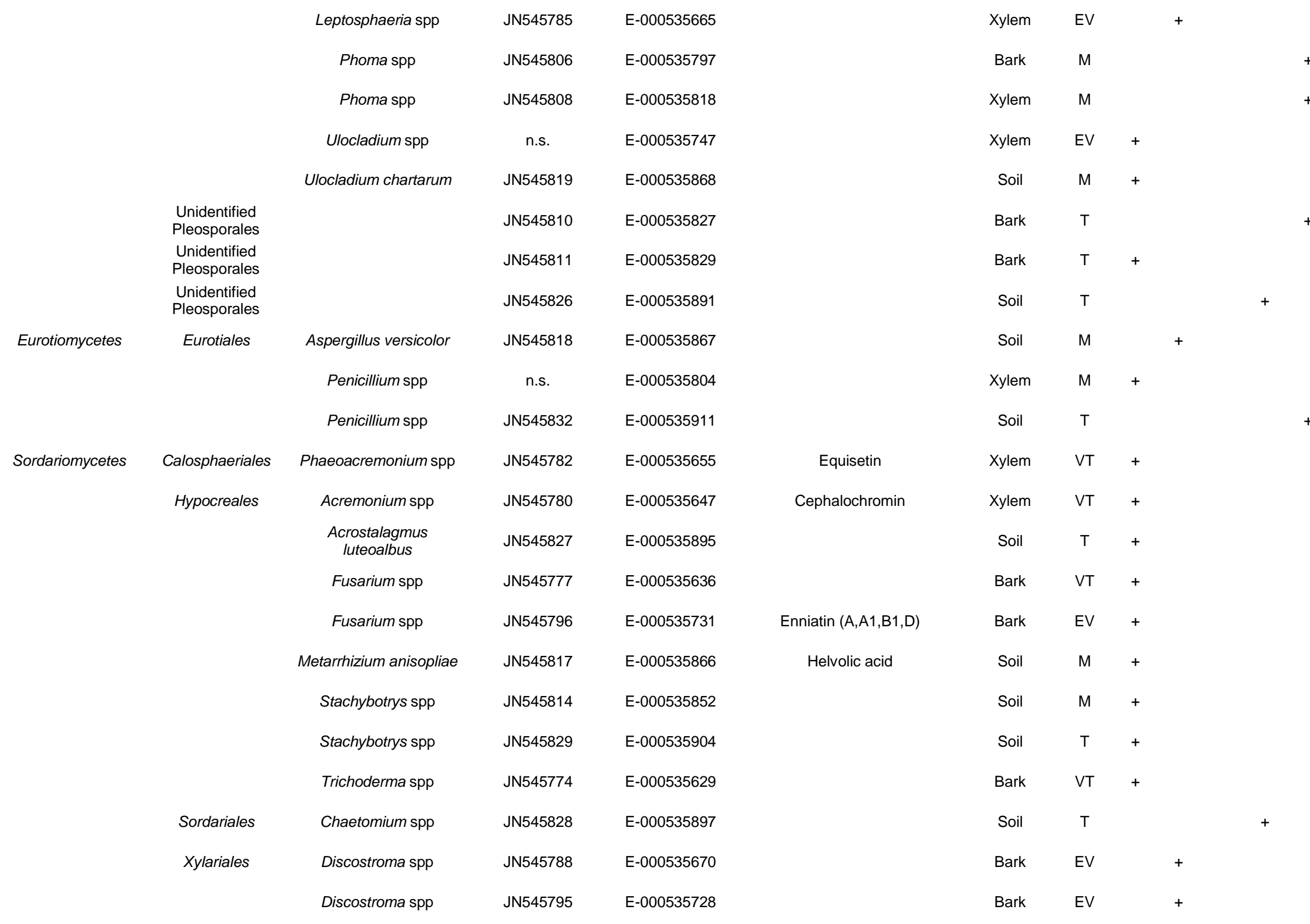




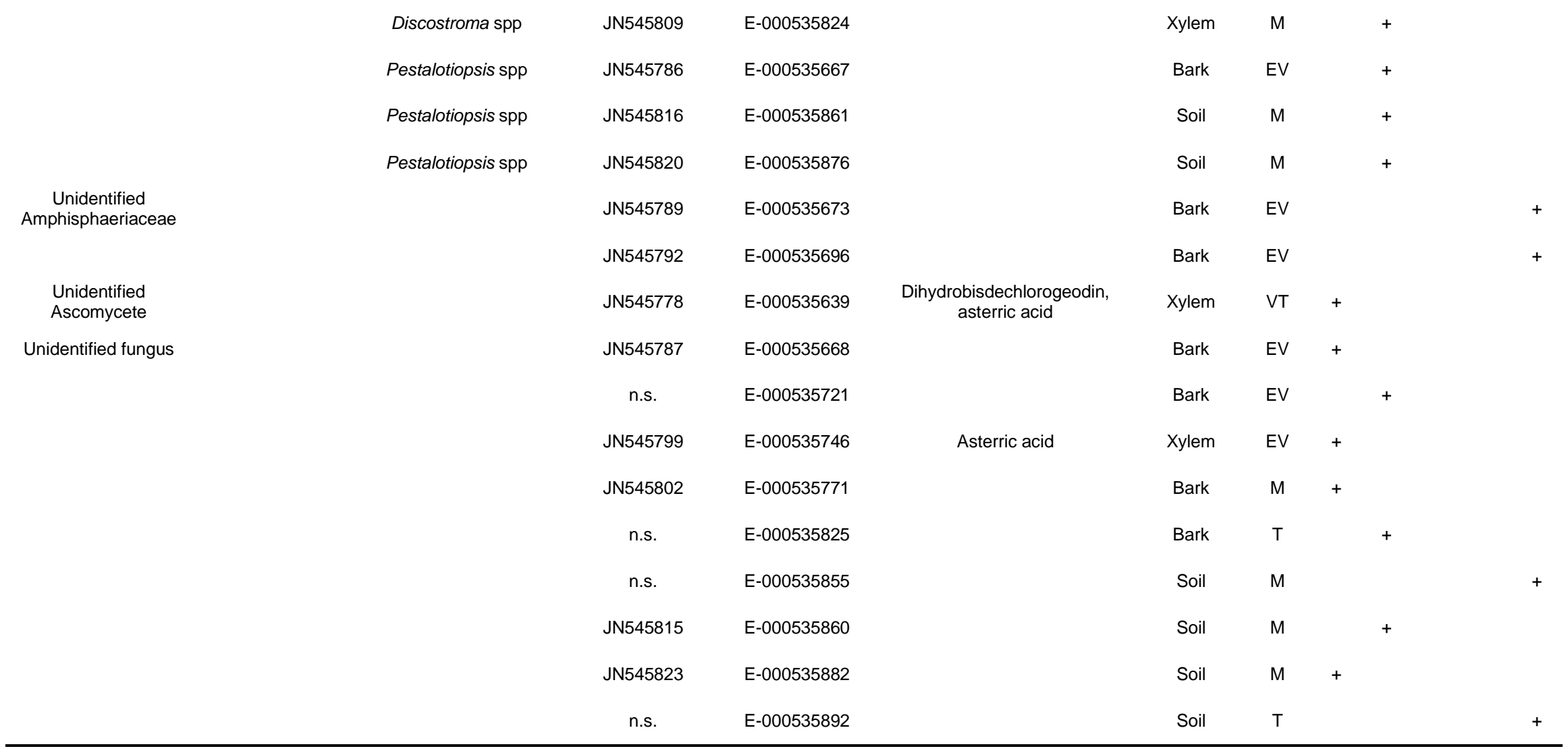

n.s.: not sequence

VT: Villamanrique del Tajo (Madrid), EV: Escuela de la Vid (Madrid), M: Membrilla (Ciudad Real), Tortuero (Guadalajara).

Sta: Staphylococcus aureus EP167, Aci: Acinetobacter baumannii (clinical isolated), Pse: Pseudomonas aeruginosa PAO1, Eco: Escherichia coli O157:H7 (CECT 5947), Can: Candida albicans

MY1055. 